\title{
The Relationship between the Artistic Qualities of He Lu's Calligraphy and the Inheritance of Traditional Culture
}

\author{
Hongyu Deng \\ Logistics Management Office, Sichuan University of Arts and Sciences, Dazhou, China \\ Email: 1tt_268@163.com
}

How to cite this paper: Deng, H. Y. (2019). The Relationship between the Artistic Qualities of He Lu's Calligraphy and the Inheritance of Traditional Culture. Chinese Studies, 8, 83-91.

https://doi.org/10.4236/chnstd.2019.83007

Received: June 20, 2019

Accepted: August 20, 2019

Published: August 23, 2019

Copyright (อ 2019 by author(s) and Scientific Research Publishing Inc. This work is licensed under the Creative Commons Attribution International License (CC BY 4.0).

http://creativecommons.org/licenses/by/4.0/

\begin{abstract}
As a contemporary calligraphist, $\mathrm{He} \mathrm{Lu}$ is famous for a new and fresh air of his calligraphy because of his learning from all the others and owning numerous excellences. At present, Chinese calligraphy is still in the category of comprehensive macro aesthetics. The analysis of the artistic characteristics and cultural connotation of his calligraphy is aiming at exploring the inheritance relationship between the artistic qualities of his calligraphy and traditional culture, which is helpful to strengthen the cultural confidence of contemporary scholars. The cultural implication in his calligraphy shows the importance of reading for calligraphists.
\end{abstract}

\section{Keywords}

He Lu, Calligraphy, Inheritance of Art

\section{Characteristics and Cultural Connotation}

\subsection{Mathematical Talent and Calligraphist}

Mr. He devoted himself to the education all his life. He was meticulous and cultivated such outstanding scientific talents as Yan Jici, Qian Sanqiang and Hua Luogeng. Moreover, he wrote Differential Calculus, a significant monograph in the field of mathematics and enjoyed a high honor in the education and science circle (Chen, 2018b). Mr. He respected Su Dongpo all his life, making calligraphy and creating poems with his life of educational career. More than 6000 poems were created in the spare time of his science and education. In his classes, he often emphasized the content beyond mathematics knowledge, for example, disseminating Chinese poetry and calligraphy and inspiring students to read more books. So his achievements in calligraphy are no less than scientific re- 
searches. He was experienced in calligraphy. Besides 800 poems, he wrote a lot of collections of calligraphy, including Xu Shu Pu (Books Family Continued), Jing Fu Dian Fu (Ode to Jingfu Palace), 37 Poems by Maotzetong, Standard Grass Calligraphy about 1000 Characters, Book Family by Sun Guoting, etc.

\subsection{Characteristics of Calligraphy}

The integration of science and art is the characteristics of He Lu's Calligraphy. He is good at calligraphy since he first learned from Yan's and Liu's calligraphy, and then from Ou's and Wang's calligraphy. So his calligraphy has his individual characteristics because of his absorption of the excellences from others'. His regular script has the feature of sharpness and prettiness from Ou's style with the charm of stroke from two Mr. Wang, whose handwriting looks neat and elegant. The structure of Chinese characters' stroke order reflects the rules and order. The calligraphy of Mr. He displays a rational and rigorous spirit which comes from his pursuit of science. Besides, his calligraphy is full of sensibility because of his love of life and temperament of literati which is reflected in his works at his pleasure. An elegant feeling of literati and a peaceful mind of scholar are embodied in his calligraphy, all of which is rooted in the Chinese culture.

\subsection{Cultural Connotation}

Mr. He learned a lot from the ancient classic calligraphy, especially from the works of Mr. Wang Xizhi and Mr. Wang Xianzhi. His work is traditionally artistic and literary talented and he is both a literati and artist. Mr. He advocated the "education for saving the nation" and the concept of "fusion of west and east" (Chen, 2018a) which was shared with the intelligence at that time, who insisted on the union to fight against the invaders. Mr. He often created calligraphy for the public for free. His creation is elegant for the sake of transmission of traditional culture. His works are embodied with the elegance and good taste and never assimilated to be worldly. Among them his lower case (regular scrip with small characters) and grass writing are the highest level.

\section{The Culture Confidence from the Inheritance of Calligraphy}

The root of an ethnic development lies in the inheritance of excellent Chinese culture and the root of a culture development lies in the inheritance of Chinese calligraphy. So the confidence in Chinese calligraphy is closely related to the culture confidence. At present, much more attention is paid to the calligraphy education. The study on the calligraphy of Mr. He is valued as the level of the inheritance of excellent culture and the highland of a national cohesiveness. Calligraphy learning doe not only mean to spell Chinese characters, but also mean to read and understand them, all of which implies that the emphasis on Chinese calligraphy relates to the culture development which is helpful to improve the confidence of calligraphist on the culture. 


\subsection{Calligraphy as a Popular Art}

Calligraphy is a traditional art in China, which embodies one's temperature and culture, whose carrier is Chinese characters which are the tool of writing and exchange of information. Besides, it is a popular art and its writing and beauty is closely related to the information of China, which requires the calligraphy must be epochal and it has an influence on the development of culture (Han \& Wang, 2015). Mr. He learned and loved the art of calligraphy all his life and his teaching notes seem to be an excellent collection of calligraphy. Calligraphy is not an art only for minority but for the public in order to inherit and develop Chinese traditional culture. Since Chinese characters can reflect the essence of Chinese culture, the calligraphy education can help more people to know Chinese culture. A better way to learn calligraphy is to form a habit of practicing it consistently and persistently. The inspiration from Mr. He is that in the spare time of teaching he studied and learned calligraphy, especially from the excellent skills of the previous calligraphers and developed into his own characteristics. Mr. He's Calligraphy with his understanding of it made a great contribution to the inheritance and development of Chinese culture.

\subsection{Confidence in Culture from Calligraphy Development}

The calligraphy of Chinese characters is an ID card in culture, which is imprinted into our deep heart. Wherever we go, it is a symbol of our identity. Chinese calligraphy is a part of Chinese excellent culture with a history of thousands years, which means a food for our spirit and a root of our cultural confidence (Jin, 2010). Today it is more important to learn calligraphy since we are in the time of the stress on socialism core values which reflect traditional Chinese culture besides the pursuit of democracy and well being. The most regions of China have got rid of the poverty in material and begun to seek the satisfaction of spirit. For that, it is calligraphy that can meet the needs. A better development of calligraphy comes from the confidence in our culture and respect for the calligraphy. Mrs. Sun Xiaoyun, Vice Chairwoman of China Calligraphy Association, said, "The confidence in culture begins the confidence in calligraphy", which points out the essence of calligraphy. Chinese calligraphy is an important part of Chinese culture. In the time of speedy development, the transmission of Chinese culture has an effect on a national spirit as well as a cultural consciousness and confidence. Every Chinese has the responsibility for the inheritance and development of an ethnic culture. Chinese culture is excellent and has a history over five thousand years, which stands like a big tree, in which The Four Books and The Five Classics are like branches and every one of us is like a green leaf. The traditional culture is a kind of nutritive solution which raises every leaf and then the big tree is growing into a power that can protect the posterity afterwards. The national cohesiveness and security sense is rooted in the traditional culture and the culture confidence lies in every one. 


\section{Artistry of He's Calligraphy and Inheritance of Traditional Culture}

The calligraphy art is a unique Chinese culture in the world and the essence of the culture. In its history a lot of calligraphers have come into being continuously and successively. Besides the study of Math, Mr. He made researches on calligraphy and developed into his own characteristics which are favored by scholars and literati because of its charm and grace (Li, 2013).

\subsection{Calligraphy Fever}

Since the reform and open-up, the economy is developing rapidly and the life of people is becoming better, so they hope a richer culture. Affected by Xi Jinping's speech and the documents from Department of Culture and Education, Chinese people have a life standard of "Good Chinese Citizens and Good Chinese Characters". Up to now, calligraphy has been a compulsory course in the primer and middle school and some universities have admitted the students of undergraduate, postgraduate and Doctor. Many communities have set up Calligraphy Writing Groups, the members of calligraphy associations and the training rooms are largely increasing. All these show a "calligraphy fever".

Chinese character is one of the oldest written languages in the world and the only hieroglyph that has been passed down today. It is the long history and unique feature that calligraphy fever was spread, which displays its magic power. Recently, the soft power from culture has played an initial part in the international competition. The aesthetical value of calligraphy is contained in the traditional Chinese culture over thousands years and surely it can stand for the soft power of Chinese cultures. He's calligraphy has a wide influence. When it was spread to Japan, his calligraphy was highlighted in the field of calligraphy, which is a great sign of Chinese culture abroad. His script is neat and beautiful, which attracts the former Prime Minister Kakuei Tanaka and even he made an invitation that Mr. He would visit Japan and make a discussion about calligraphic art. But it is a pity for the exchange of culture between China and Japan that Mr. $\mathrm{He}$ passed away and the visit did not come true. It is because many calligraphers like Mr. He earnestly study the art that the calligraphy fever comes into being, which shows a great contribution to the art. The calligraphy fever is an expectation of Mr. He for he publicized it in his teaching.

\subsection{Personality Affected by Calligraphy}

"My calligraphy would not be sold how much paid, but it would be never paid if friends like". This is a principle about his calligraphy all his life. So his works have been known widely. His quality is worth respecting and following that the art of calligraphy does not aim at selling but affecting one's personality. A saying is that "an art work is accepted in terms of one's personality", which means that whether lower or higher the personality of a calligrapher is will have a worse or better influence on his creation and acceptance because a piece of work is prop- 
erly reflecting his temperament and character. Calligraphist Yan Zhenqing is called "the second calligraphist of cursive handwriting of the Earth", whose handwriting work "A Memorial to Nephew" recalled his nephew who died in the "An Shi Rebellion". This work has been praised till now since its content and ups and downs of handwriting indicates his grief when his nephew was killed in the riot. A piece of calligraphy work often is way to express one's feeling and a true motion is being displayed. "A right heart is a right writing", which was an answer of the famous calligraphist Liu Gongquan to the Emperor at that time (Mo, 2008). When learning calligraphy, a learner follows the style of the previous masters and then gets a good inspiration of personality cultivation.

\subsection{Competence Influenced by Calligraphy}

Mr. He's achievement in Math is no less than in calligraphy. In fact, the study of Math and calligraphy plays a mutually complementary role. An unrestrained style of calligraphy will help form an easy and free thinking. In the spare time of Math study, handwriting helped him to relaxation or entertainment. Besides, calligraphy can improve the observational ability of students. Today, calligraphy has been a course in the primary school, which shows it has been paid an increasing attention to because it can do good to the comprehensive competences of students, especially the observational ability since when they learn it, students must carefully observe the structure of every character, the strokes and gestures of brush or pen's movement.

The old saying is that "the handwriting art originates the nature" (Wang \& $\mathrm{Xu}, 2018)$. Calligraphy requires rich imagination. When a character is written, the expression and description of strokes and forms come from the careful observation of life and nature. Only that can the character looks beautiful. An illustration is that Zhang $\mathrm{Xu}$, the master of grass writing in Tang Dynasty, grasped the way of stroke's moving when he saw a woman named Gongsun performing swordplay. In a word, a good work of calligraphy art needs experiences of life and rich imagination.

What's more is that the calligraphy is helpful to improve the thinking pattern of students. When they copy, students should represent the process of a character's handwriting and consider many problems, such as the direction of a character, heavy or light milk, speed of brush movement and the shape of strokes, etc., and the most important is that the spirit in a character should be grasped. The previous masters' calligraphies appear mellow and living. Whether the characters look leaning or upright, the color of milk is heavy or light and the strokes are thick or thin reflect the contradiction of Chinese handwriting, yet it is required to be harmonious in the contradiction. This is worth thinking and studying.

The old saying that "the fragrance of plum blossoms comes from the hard coldness" implies that it is a long and hard experience to learn handwriting. No more other subjects than the calligraphy can improve the concentration and 
endurance. Today, the cyber games, short videos, popular songs and blockbusters have been the favor of children, especially "the Honor of Kings", a game from Tencent, has fascinated numerous children. It is not exaggerated to say that thousands million people have been fascinated with Tik Tok, Huosan, Kuaishou (GIF Quick Hand), etc. The time is skilled meaninglessly. It is more valuable for the children to obtain knowledge, especially the Chinese traditional culture though the games in the cyber are attractive. Handwriting can help them to calm down and focus on a thing. If they are helped to like Chinese art, children will decrease the consumption of time on the network.

\subsection{Calligraphy and Other Subjects}

Calligraphy is extensive and profound. The study of it can help to learn other subjects. As to Mr. He himself, first he is a famous mathematician who has a great influence in the history of math. He published On Quadratic Equation and On Determinant. Besides, his calligraphy is unusual. He Peiyan, his offspring, compiled Calligraphy Collection of $\mathrm{He} \mathrm{Lu}$, which contains ten types of works and represents his achievement in the art. It is turned out to be that calligraphy has a special function to develop one' thinking pattern, concentration and endurance. Therefore, calligraphy is closely related to other subjects and they play a mutual role in the development of children.

\section{Influence of He Lu's Calligraphy}

When the living condition becomes better and better, people are sure to seek higher level of life besides the satisfaction with a material level. "Calligraphy Fever" is an example, which shows that the people of all ages and all walks desire a spiritual enjoyment. In park, you will see the old people are practicing handwriting; in school, calligraphy as a course is trained; and even in plants, there are groups of interest in calligraphy (Wu \& Zhang, 2013). Here and there, He Lu's calligraphy is copied by his fans.

\subsection{A Warning on Modern Calligraphers}

Mr. He was learned and versatile and read The Four Books and The Five Classics carefully. In 1903, he was admitted by Chengdu Mechanics College because of his excellence in literature and on the occasion of interview he answered questions so right and fluently that he got No. 1. In schooling, he successively got the rewards of "Excellences" and was sent on recommendation to Nanyang Mission College and then was sent to University of Lyon at public expense. Mr. He has been diligent in learning and got great achievements, which is a model for the others afterwards. Today, many calligraphers do not like reading and have a heavy taste of commerce. They pay more attention to the forms and less to the inner cultivation. So their handwritings lack in literary quality and culture. Calligraphy is an art and the literary quality and personality of a calligrapher is especially important for a higher level of the art. 


\subsection{Influences on Personality of Modern Calligraphers}

He Lu's work of handwriting would not be paid if anyone likes, which is a model for the modern calligraphers. The art of calligraphy should not be judged by the commercial value. There are few masters in calligraphy because of the excessive sake of commercial values. The art of calligraphy should be public and popular, which is for the sake of the inner and higher distillation. Often there are knockoffs of masters in calligraphy, who are indeed paid much attention to after they are artificially decorated and much commercial value is achieved. A learner of calligraphy should discard the concept from the start. All his life Mr. He worked hard in academy and reached higher level in Math and Calligraphy. Besides, his spirit that he defied the oppression from the authority and lives helped him to achieve greatly. Learning calligraphy requires a learner to read firstly and to cultivate his personality. It is alike to the Chinese culture which has a history over five thousand years and survives today. Similarly, a learner with inner cultivation and diligence can achieve greatly (Yan, 2014).

\subsection{Influence on Students' Culture}

The art of calligraphy is the crystallization of Chinese culture, which has a deep cultural connotation and attraction. Its inheritance and development needs the younger, especially the students have a passion to practice it (Yang \& Liu, 2016). Though many students of Mr. He have become famous mathematicians, yet in his class the calligraphy was stressed, which had great influences on the cultivation of students. A better calligrapher needs a deeper culture, which is significant for students to read widely and to think over. Learning calligraphy, students will feel it is broad and profound and then attractive. Besides, students will feel proud of his nation and an affection of patriotism is aroused from their hearts. In the process of the inheritance of Chinese Culture, a perfect personality is developed. The inheritance and development of Chinese calligraphy in the long history of thousands years is worth rethinking, which brings us the sense of responsibility and mission to carry forward. The practice of calligraphy can help students to form the habit of reading more and to improve their spirits. In essence, the education of calligraphy is about the education of aesthetics. A further learning of calligraphy will improve students' power to recognize, feel, differentiate, and create. Accordingly, the ability of appreciating calligraphy art will improve greatly (Zhu, 2011).

\section{Conclusion}

Chinese calligraphy is an art whose carrier is Chinese character and an excellent culture which has a history over five thousand years. It has been fused into the national spirit and proudly it is existing in the world with its deep cultural connotation including phonics, literature, history and aesthetics, etc. As the prosperity of Chinese Ethnic, we have a responsibility to learn and study it. Mr. $\mathrm{He}$ has always been respected because of his good personality and great achieve- 
ments in calligraphy. The time requires more scholars like him to work hard in academy. At the last moment of his life, he was working and grasping pen firmly in his hands. Mr. He left us a great wealth. He solved many difficult questions in the field of Math; he created many pieces of excellent works in calligraphy and most valuable is his spirit, which is worth studying and considering. It is valuable for us to study him. He has absorbed advantages of many calligraphers and become his own individualism. His regular script looks sharp and pretty like the style of Ouyang Xiu's and the taste of Wang Xizhi and Wang Xianzhi's and the feature of characters on the gravestone in Han Dynasty. His calligraphy is popular in Japan and the former Prime Minister Kakuei Tanaka was very fond of his calligraphy and invited him to visit Japan. It was a pity that Mr. He died before his visit. Mr. He is a famous mathematician, a poet of over 800 poems, studying in France in his earlier age, a famous professor in the Republic of China and the People's Republic of China. His experiences and thought are outstanding and his culture temper is exceeding all ordinary people. So it is significant to study his calligraphy, which can help to overcome the flippancy in calligraphy, to refuse the popular style and to attack on the bad calligraphy which fools common people.

\section{Conflicts of Interest}

The author declares no conflicts of interest regarding the publication of this paper.

\section{References}

Chen, Y. F. (2018a). Calligraphy Art Ecology of Characters on Jiang's Gravestones in Sui Dynasty. Journal of Hezhou College, No. 2.

Chen, Z. L. (2018b). State Quos, Problems and Hopes of Chinese Calligraphy Study. Chinese Calligraphy, No. 3.

Han, B. S., \& Wang, H. F. (2015). Influences on Modern Calligraphy Education from Book Family by Sun Guoting. In To Deepen Education Reform and Improve Education Quality.

Jin, X. R. (2010). Culture Spirit of Chinese Traditional Calligraphy. In Paper Collection of Fourth Session of Yuelu Forum on Chinese Culture and Medicine.

Li, C. L. (2013). He Lu: Forerunner of Modern Mathematics Education in China. Journal of Inner Mongolia Normal University (Education Science), No. 2, 10-13.

Mo, B. X. (2008). Inspirations on Calligraphy Art from Liang Qichao's Aesthetic Thought. In Paper Collections of Beginning of Chinese Modern Aesthetics and Literature Theory: Chinese Modern Aesthetics, Literature Theory and Liang Qichao.

Wang, W. P., \& Xu, H. (2018). The Influences on Teenagers' Life Concept from Calligraphy: A Case of Wang Xizhi and His Calligraphy. Journal of Jing De Zheng College, No. 1, 125-129.

Wu, C. H., \& Zhang, P. (2013). The Past, Present and Future of Calligraphy: An Overview of Academic Forum on International Show of Chinese Calligraphy Art. Chinese Calligraphy, No. 9.

Yan, G. D. (2014). Aesthetics Change and Culture Consciousness in the Context of Glo- 
balization. In Aesthetics and Art in the New Century: Paper Collection of Seventh Session of Jiangsu Art Member.

Yang, L. S., \& Liu, D. (2016). Jing Hengyi’s Study of Cuan Baozi's Gravestone Characters. Chinese Calligraphy, No. 22.

Zhu, S. (2011). The Study History of Chinese Calligraphy History: Center as Wang Cenbo, Sha Menghai, Sun Yiti, Hu Xiaoshi, Zhu Jia. Paper Collection of Specific and General: Individual and Problem in Art History. 